\title{
Framing Pemberitaan Diskresi Ahok untuk Reklamasi Jakarta pada Majalah Tempo
}

\author{
Fuji Lara Sakti Afdiningsih ${ }^{1}$, H. A. Sihabudin, Puspita Asri Praceka \\ Jurusan Ilmu Komunikasi, Fakultas Ilmu Sosial dan Ilmu Politik \\ Universitas Sultan Ageng Tirtayasa
}

\begin{abstract}
This paper examines the additional 15 percent of Basuki Tjahaja Purnama (Ahok) discretion on reclamation for project developers. This paper aims to determine how Ahok's discretion in Tempo magazine is constructed. The method of framing analysis of Robert $N$. Entman is employed. The news articles are taken from Tempo Magazine issues of 11 to 17 April 2016, 23 to 29 May 2016, and 20 to 26 June 2016. The samples are 8 news articles. Utilizing the analysis framing model by Robert $N$. Entman, this paper examines four devices unit of analysis: define problems, diagnose causes, make moral judgments, and treatment recommendation. The paper shows that Tempo is criticizing Ahok discretion. Tempo urges KPK to investigate the accuracy of Ahok discretion, because there is no legal foundation and the source of the problem of bribery reclamation cases. Aguan is suspected to participate in blocking the additional contribution. It is suggested that Tempo should reduce anonymous source in reporting so that the information is more reliable.
\end{abstract}

Keywords: discretion of Ahok, framing, reclamation Jakarta, Tempo Magazine

Abstrak
Topik penelitian ini perihal diskresi kontribusi tambahan 15 persen
yang dilakukan oleh Basuki Tjahaja Purnama untuk pengembang
proyek reklamasi. Tujuan penelitian ini adalah untuk mengetahui
bagaimana Majalah Tempo mengkonstruksi diskresi Ahok dalam
kasus reklamasi Jakarta. Metode penelitian yang digunakan adalah
metode penelitian kualitatif dengan pendekatan paradigma konstruk-
tivisme dengan teknik analisis framing model Robert N. Entman.
Berita yang menjadi objek penelitian diambil dari Majalah Tempo
yang terbit pada tanggal 11-17 April 2016, 23-29 Mei 2016, dan 20-
26 Juni 2016 lalu yang berjumlah 8 berita. Dengan menggunakan

${ }^{1}$ Korespondensi Penulis

Fuji Lara Sakti Afdiningsih, Jurusan IImu Komunikasi, Fakultas IImu Sosial dan IImu Politik, Universitas Sultan Ageng Tirtayasa. Jl. Raya Pakupatan Km 4.

fujiafdiningsih@gmail.com 
model analisis framing model Robert N. Entman, maka berita ini akan diteliti dengan menggunakan empat perangkat unit analisis: define problems, diagnose causes, make moral judgement, dan treatment recommendation. Hasil penelitian menunjukkan Tempo mengkritisi diskresi yang dilakukan oleh Ahok. Tempo menghimbau KPK agar menyelidiki ketepatan diskresi yang dilakukan Ahok tersebut, karena tidak ada dasar hukum yang jelas dan menjadi sumber masalah dari kasus suap reklamasi. Aguan diduga ikut menghadang kontribusi tambahan tersebut. Tempo sebaiknya mengurangi narasumber anonim dalam pemberitaannya agar kebenaran informasi menjadi lebih kuat.

Kata kunci: diskresi Ahok, framing, Majalah Tempo, reklamasi Jakarta

\section{Pendahuluan}

Reklamasi merupakan kegiatan melakukan pengerukan wilayah pantai menjadi daratan untuk proses pembangunan gedung, pemukiman, ataupun tempat wisata. Reklamasi menjadi persoalan yang menyangkut hajat hidup orang banyak. Di Indonesia, terdapat beberapa wilayah reklamasi yang mendapat penolakan dari masyarakat sekitar, Bali, Kalimantan, dan juga Jakarta. Reklamasi di Jakarta bukan masalah yang baru terjadi, namun dalam 2 tahun terakhir reklamasi menjadi masalah yang pelik bagi masyarakat Jakarta. Sehingga membuat masyarakat pada akhirnya membentuk suatu gerakan untuk menyatukan suara, menolak kegiatan reklamasi yang dilakukan oleh Pemerintah DKI Jakarta.

Penolakan dilakukan karena reklamasi dianggap bukan sebagai solusi untuk memperbaiki permasalahan lingkungan yang terjadi di Jakarta, tetapi menjadi masalah baru. Masyarakat merasa dirugikan dengan penggusuran dan pengerukan wilayah pesisir pantai. Semenjak reklamasi dilakukan, kehidupan masyarakat sekitar menjadi semakin sulit. Lingkungan tangkap ikan yang menjadi mata pencaharian utama masyarakat tercemar, menyebabkan biota laut perlahan mati sehingga nelayan sulit dalam mencari tangkapannya. Permasalahan yang terjadi menjadi dasar masyarakat wilayah pesisir pantai akhirnya membuat gerakan untuk menolak reklamasi Jakarta.

Masalah reklamasi tidak hanya terjadi pada masyarakatnya, juga terjadi pada masalah regulasi yang menjadi hal yang pelik dalam kasus reklamasi. Rancangan peraturan daerah yang di dalamnya terdapat pembahasan terkait reklamasi, belum juga disahkan karena belum menemui kesepakatan dalam tubuh legislatif. Proyek reklamasi sudah mulai berjalan, pihak pengembang sudah mulai melakukan pengerukan walaupun aturan belum juga dirampungkan. Ahok sebagai orang nomor satu di DKI Jakarta, melakukan inisiasi dengan mengeluarkan diskresi kontribusi tambahan 15 persen untuk pengembang yang ikut andil dalam proyek reklamasi.

Menurut kamus hukum (BPHN), diskresi diartikan sebagai kekuasaan bertindak dari pejabat pemerintah dalam situasi tertentu, berdasarkan keyakinannya yang mengarah pada kebaikan, keadilan dan kelayakan. Dalam kasus reklamasi Jakarta, 
Ahok membuat kebijakan diskresi sebagai keputusan yang mendesak, karena belum rampungnya Raperda Tata Ruang dan Raperda Zonasi Wilayah Pantai Utara Jakarta yang menyangkut kontribusi tambahan 15 persen untuk reklamasi Jakarta. Sehingga diskresi dianggap sebagai solusi, untuk mengatasi permasalahan perizinan pengembang.

Namun beberapa waktu lalu, sekitar pertengahan Mei 2016, media massa dihebohkan oleh amuk Ahok terhadap Majalah Tempo yang memberitakan kasus reklamasi Teluk Jakarta. Ahok menganggap pemberitaan Tempo memfitnah dan terlalu menyudutkan Gubernur DKI Jakarta tersebut. Majalah Tempo mengangkat pemberitaan perihal kasus reklamasi Teluk Jakarta dalam tiga edisi khusus, namun yang menjadi sumber masalah adalah edisi kedua yang berjudul "Amuk Reklamasi”, dalam majalah tersebut terdapat berita yang mengkaji perihal diskresi atau kebijakan Ahok dalam memberikan keputusan perihal pembayaran kontribusi tambahan dari pengembang proyek reklamasi.

Dalam pemberitaan tersebut Tempo juga menjabarkan data berita acara rapat pembahasan kewajiban tambahan 15 persen, dari narasumber yang disembunyikan. Kontribusi tersebut merupakan keputusan Ahok yang diwajibkan untuk pengembang proyek reklamasi Jakarta. Dalam data tersebut tertulis data-data perusahaan yang ikut dalam pembangunan proyek reklamasi. Data ini menjadi alat untuk Tempo dalam mengkritisi dan membongkar kasus reklamasi yang kini sedang diselidiki oleh KPK tersebut. Dalam beritanya, Tempo mengatakan bahwa Ahok telah melakukan barter dalam proyek reklamasi yang kini sedang digarapnya dengan pengembang PT. Agung Podomoro Land. Kalimat barter yang dikeluarkan Tempo mendapat respon dari Gubernur DKI Jakarta tersebut, Ahok tidak terima jika dikatakan melakukan barter dengan pihak pengembang. Sebagai pejabat negara, Ahok meyakini bahwa keputusan diskresi yang dilakukannya guna untuk keberlangsungan proyek reklamasi. Respon tersebut mengarah pada pengancaman Ahok kepada pihak redaksi Tempo yang akan dilaporkan kepada pihak berwajib, karena isi berita tersebut dianggap telah menyudutkan dan memfitnahnya. Ahok pun mempertanyakan dari mana pihak redaksi Tempo mendapatkan berita acara rapat tersebut, karena berita acara rapat merupakan data rahasia Pemerintah DKI Jakarta. Diskresi Ahok tersebut akhirnya melahirkan pro dan kontra.

Respon tidak hanya datang dari Ahok semata, para pendukung Ahok atau yang akrab disebut Teman Ahok juga angkat suara. Rudi Valinca dalam akun Twitternya, “@kurawa”, menyebutkan bahwa wartawan Tempo tidak cover both side dalam memperoleh informasi, dan Tempo dikatakan sedang dalam kesulitan ekonomi dan membutuhkan penyelamatan. Dengan menyerang Ahok, Tempo berharap dapat bekerjasama dengan Ahok.

Serangan Tempo ini mengejutkan banyak kalangan, karena Tempo yang selama ini dianggap berkawan dengan Ahok dalam pemberitaannya kali ini berbanding terbalik dengan pemberitaan reklamasi yang diterbitkan redaksi majalah Tempo pada akhir Mei lalu. 
Kasus reklamasi sedang hangat diperbincangkan, perihal perizinan yang legal atau tidak, perihal nasib warga setempat yang terkena gusuran, perihal permainan pengembang dan pemerintah, dan lain sebagainya. Media massa baik cetak ataupun elektronik begitu masif memberitakan kasus reklamasi tersebut. Sebagai orang nomor satu di DKI Jakarta, Ahok kian menjadi sorotan dalam setiap pemberitaan terkait reklamasi.

Majalah Tempo dalam 7 bulan terakhir tahun 2016 telah menerbitkan 3 edisi yang membahas perihal kasus reklamasi, edisi pertama terbit pada pertengahan April tertanggal 11-17 April dengan judul "Reklamasi Tujuh Keliling", edisi kedua tertanggal 23-29 Mei dengan judul "Amuk Reklamasi”, dan edisi ketiga 20-26 Juni dengan judul "Duit Reklamasi Untuk Teman-Teman Ahok".

Tempo merupakan media massa yang terbilang lama dalam melakukan kerjakerja jurnalistik, yaitu sejak tahun 1971. Dalam catatan sejarah, media pada masa orde baru media adalah alat politik kekuasaan. Berita yang ditulis tidak boleh bertentangan dengan pemerintah. Media disetir dalam kerja-kerjanya. Tempo merupakan media yang cukup berani untuk mengkritisi pemerintah pada saat itu, hingga terjadi pembredelan. Walaupun demikian, media massa ini masih dapat berkiprah di dunia jurnalistik hingga hari ini dengan karakteristiknya yang tidak berubah.

Jelang pilkada 2017, kasus reklamasi adalah senjata bagi para pelaku politik untuk menyerang lawan politiknya. Media sebagai pilar demokrasi yang ke-4 kini dipertanyakan fungsinya, karena digunakan sebagian golongan untuk kepentingan politik. Begitupun dengan internalisasi media, independensi media juga ikut dipertanyakan karena dalam melakukan pemberitaan condong berat sebelah atau mendukung salah satu pihak dan menyerang pihak lainnya.

Cara untuk menganalisis pemberitaan media massa adalah dengan menggunakan analisis framing. Analisis framing membedah cara-cara atau ideologi media saat mengkonstruksi fakta. Analisis ini mencermati strategi seleksi, penonjolan, dan pertautan fakta ke dalam berita agar lebih bermakna, lebih menarik, lebih berarti atau lebih diingat, untuk menggiring interpretasi khalayak sesuai perspektifnya.

Pada penelitian ini penulis menggunakan analisis framing sebagai pisau analisis, untuk mencari tahu bagaimana Majalah Tempo membingkai dan memaknai diskresi Ahok untuk reklamasi dan posisi Tempo dalam pemberitaannya. Dalam berbagai macam tudingan yang melayang kepada Tempo, framing merupakan pisau analisis yang tepat untuk mencari tahu makna apa yang tersirat dalam sebuah pemberitaan media massa. Sehingga penelitian ini tersusun dengan judul "Konstruksi Diskresi Ahok untuk Reklamasi (Analisis Framing Pemberitaan Reklamasi Jakarta Pada Majalah Tempo)"

\section{Kajian Pustaka}

Framing adalah pendekatan untuk mengetahui bagaimana perspektif atau cara pandang yang digunakan oleh wartawan ketika menyeleksi isu dan menulis berita. 
Cara pandang atau perspektif itu pada akhirnya menentukan fakta apa yang diambil, bagian mana yang ditonjolkan dan dihilangkan, serta hendak dibawa ke mana berita tersebut. Karenanya, berita menjadi manipulatif dan bertujuan mendominasi keberadaan subjek sebagai sesuatu yang legitimate, objektif, alamiah, wajar, atau tak terelakkan. (Sobur, 2006:162)

Pembingkaian diproses melalui konstruksi melihat realitas sosial, sehingga menghasilkan makna tertentu. Kerja jurnalistik ditentukan dari konstruksi dan makna tersebut, untuk menentukan narasumber dalam menggali informasi dan melakukan verifikasi, dan mengkaji suatu persitiwa dari sudut pandang mana. Sehingga dapat diketahui dengan cara apa sebuah realitas sosial ditandakan, yang kemudian diterbitkan menjadi berita. Pengambilan keputusan tersebut melibatkan nilai dan ideologi para pekerja jurnalistik yang terlibat dalam proses produksi sebuah berita.

Permasalahan reklamasi pantai utara Jakarta sudah berlangsung sejak tahun 2003 dan sudah berulang kali keluar masuk meja hijau. Kini reklamasi kembali menemui kemelutnya. Berdasarkan pemberitaan dari media massa, reklamasi pantai utara Jakarta kembali mencuat saat Komisi Pemberantasan Korupsi (KPK) melakukan operasi tangkap tangan Ketua Komisi D DPRD, M Sanusi, yang kemudian disusul oleh penyerahan diri Presiden Direktur PT. Podomoro Land, Ariesman Widjaja, kepada KPK. Proyek yang selama ini tidak masif diberitakan kini menjadi perhatian publik. Setelah itu, muncul banyak perdebatan tentang reklamasi pantai. Kali ini, tidak hanya dampak lingkungan yang dipermasalahkan. Perizinannya pun menimbulkan perdebatan dalam jajaran Pemerintah DKI Jakarta dengan Pemerintah Pusat, serta upaya pengembang untuk melakukan suap kepada pejabat berwenang. Kontribusi tambahan 15 persen dianggap memberatkan pengembang, karena harus mengeluarkan biaya yang tidak sedikit. Oleh karena itu, beberapa pengembang merapatkan diri kepada pejabat berwenang untuk melakukan lobi agar kontribusi tambahan diturunkan menjadi 5 persen.

KPK melakukan penyelidikan perihal kontribusi tambahan proyek reklamasi pantai utara Jakarta. Diduga terdapat tindak korupsi dan suap antara pemerintah dengan pengembang. Kontribusi tambahan proyek tersebut merupakan sebuah diskresi yang diberikan oleh Basuki Tjahaja Purnama kepada pengembang PT. Agung Podomoro Land dan pengembang lain yang melakukan pembangunan pada proyek reklamasi. Berdasarkan laporan dari KPK yang dimiliki oleh Tempo, terdapat kontrak 13 pekerjaan Muara Wisesa senilai Rp 392,6 miliar. Total biaya yang sudah dikeluarkan Rp 218,7 miliar. Sedangkan jenis pekerjaan yang digarap antara lain pembangunan dan pengadaan mebel rumah susun sederhana sewa (rusunawa) di Jalan Daan Mogot, Jakarta Barat, pengadaan rumah pompa dan fasilitasnya, serta penertiban kawasan prostitusi Kalijodo. Berdasarkan temuan data tersebut, lahir kecurigaan bahwa terdapat barter dalam proyek kontribusi tambahan untuk reklamasi Jakarta. Komisi Pemberantasan Korupsi sedang mendalami dasar hukum perihal kontribusi tambahan proyek reklamasi pantai utara Jakarta yang dikeluarkan oleh Basuki Tjahaja Purnama, untuk mengetahui apakah benar terjadi penyimpangan. 
Basuki Tjahaja Purnama memberikan diskresi kepada pihak pengembang dengan alasan ketika sebuah peraturan tidak ada, pejabat boleh membuat kebijakan sendiri. Terkait dengan kasus diskresi Ahok untuk reklamasi Jakarta, tentu media massa memiliki ruang khusus untuk menekankan penonjolan isu terkait reklamasi Jakarta. Ada aspek-aspek yang ingin mereka sampaikan dan mempengaruhi pandangan khayalak.

\section{Metode}

Dalam penelitian kali ini, penulis menggunakan metode kualitatif sebagai metode penelitian. Penelitian kualitatif dilakukan karena peneliti ingin mengeksplor maknamakna dari pemberitaan Majalah Tempo tentang diskresi Ahok untuk reklamasi Jakarta, dan juga ingin mengetahui bagaimana wartawan dan media massa mengkonstruksi realita sosial menjadi sebuah berita yang disebar luaskan kepada khalayak.

Analisis framing adalah analisis yang dipakai untuk melihat bagaimana media mengkonstruksi realitas, untuk melihat bagaimana peristiwa dipahami dan dibingkai oleh media. Sebuah metode melihat cara media bercerita atas peristiwa, cara tersebut tergambar pada "cara melihat" terhadap realitas yang dijadikan berita. Metode semacam ini tentu saja berusaha mengerti dan menafsirkan makna dari suatu teks dengan jalan menguraikan bagaimana media membingkai isu. Peristiwa yang sama bisa jadi dibingkai secara berbeda oleh media (Eriyanto, 2002:10).

Peneliti menggunakan analisis framing Robert N. Entman sebagai pisau analisis untuk mengetahui bagaimana konstruksi berita diskresi Ahok untuk reklamasi Jakarta pada majalah Tempo. Entman dalam Eriyanto (2002) membagi analisis framing dalam empat elemen, yaitu; Define problems, elemen ini menekankan bagaimana peristiwa dipahami oleh wartawan. Diagnose causes, elemen framing untuk membingkai siapa yang dianggap sebagai aktor dari peristiwa. Make moral judgement, elemen framing yang dipakai untuk membenarkan/memberi argumentasi pada pendefinisian masalah yang sudah dibuat. Treatment recommendation, elemen ini dipakai untuk melihat apa yang dikehendaki oleh wartawan, jalan apa yang dipilih untuk menyelesaikan masalah.

Paradigma konstruktivis membantu peneliti untuk melihat bagaimana wartawan dan media massa mengkonstruksi fakta realitas sosial dalam sebuah berita yang dipercaya sebagai suatu kebenaran. Paradigma konstruktivis mempunyai posisi dan pandangan tersendiri terhadap media dan teks berita yang dihasilkannya.

Unit analisis data pada penelitian ini adalah Majalah Tempo edisi 11-17 April 2016, edisi 23 Mei-29 Mei 2016 dan edisi 20-26 Juni 2016 yang mengangkat berita perihal kasus reklamasi Jakarta, pemberitaan tersebut menjadi laporan utama Tempo. Terdapat dua belas berita yang peneliti pilih untuk dianalisis, 8 berita diantaranya membahas diskresi Ahok terkait kontribusi tambahan 15 persen (Tabel 1).

Pada penelitian ini dokumentasi digunakan sebagai teknik pengumpulan data. Data berupa berita perihal diskresi Ahok untuk reklamasi Jakarta, pada Majalah 
Tempo edisi tahun 2016, yaitu April, Mei, dan Juni. Selain itu, dokumentasi dilakukan dengan mengumpulkan data yang membahas kasus Tempo dan Ahok, melalui media online, media sosial, dan forum-forum diskusi.

Tabel 1. Judul Berita Unit Analisis

\begin{tabular}{|l|c|l|}
\hline No & \multicolumn{1}{|c|}{ Edisi } & \multicolumn{1}{c|}{ Judul Berita } \\
\hline 1 & $11-17$ April 2016 & Tiga Relasi Suap Reklamasi \\
\hline 2 & $11-17$ April 2016 & Geliat Naga Pertama \\
\hline 3 & $11-17$ April 2016 & Dua Kaki Staf Basuki \\
\hline 4 & $11-17$ April 2016 & Tarik Ulur Pasal Kontribusi \\
\hline 5 & $11-17$ April 2016 & Reklamasi Penuh Kontroversi \\
\hline 6 & $11-17$ April 2016 & Laut Diuruk Sedimen Menumpuk \\
\hline 7 & 23-29 Mei 2016 & Petunjuk Baru dari Jalan S. Parman \\
\hline 8 & 23-29 Mei 2016 & Kontroversi Diskresi Basuki \\
\hline 9 & 23-29 Mei 2016 & Tangan Aguan Menghadang Kontribusi Tambahan \\
\hline 10 & 20-26 Juni 2016 & Dari Pantai Mutiara Ke Teras Balai Kota \\
\hline 11 & 20-26 Juni 2016 & Duo Kakap Konco Gubernur \\
\hline 12 & 20-26 Juni 2016 & Proposal Dahulu Relawan Kemudian \\
\hline
\end{tabular}

\section{Hasil dan Pembahasan}

Permasalahan terkait "diskresi" Tempo menuliskan bahwa Ahok berlindung di balik diskresi yang dilakukannya. Diskresi yang dilakukan oleh Basuki dianggap sebagai terobosan baru oleh Tempo, namun memiliki catatan penting yang harus dilakukan pengawasan, karena akibat dari diskresi tersebut melahirkan masalah baru yaitu penyelewengan yang dilakukan oleh oknum pencari keuntungan. Tempo juga menjelaskan pengertian diskresi berdasarkan Undang-undang Nomor 30 Tahun 2014 tentang Administrasi Pemerintahan, dan juga melakukan verifikasi ke beberapa pengamat pemerintahan perihal ketepatan diskresi yang dilakukan Ahok tersebut.

Peneliti menilai bahwa Tempo ingin KPK menyelidiki perihal ketepatan diskresi yang dilakukan Ahok tersebut. Mengapa menjadi bermasalah? Karena Ahok bersikeras bahwa kebijakannya tersebut tepat untuk mengatasi masalah reklamasi, berangkat dari Keputusan Presiden Nomor 52 tahun 1995 dan Undang-undang Nomor 30 tahun 2014 Ahok meyakini keputusannya itu tepat. Diskresi menjadi buah bibir di beberapa kalangan karena landasan hukum yang diyakini Ahok dianggap tidak relevan. Undang-undang Nomor 30 Tahun 2014 tentang Administrasi Pemerintahan belum disahkan ketika Ahok mengeluarkan diskresi dan Keputusan Presiden tahun 1995 tersebut juga tidak relevan untuk dijadikan landasan karena adanya peraturan-peraturan baru. Sehingga diskresi ini masih dalam perdebatan dan penyelidikan KPK untuk mengetahui apa motif di belakang kebijakan tersebut. Diskresi tersebut perihal aturan kontribusi tambahan 15 persen yang harus dibayarkan pengembang proyek reklamasi, yang kini aturan tersebut menjadi sumber 
masalah dari kasus suap pengembang dengan oknum pemda DKI Jakarta.

Berikut peneliti akan membahas undang-undang tentang diskresi, undangundang tersebut peneliti dapatkan dari website (http://infohukum.kkp.go.id), untuk mengetahui bagaimana prosedur dalam melakukan diskresi.

Undang-undang Nomor 30 tahun 2014 Pasal (1), Diskresi adalah Keputusan dan/ atau Tindakan yang ditetapkan dan/atau dilakukan oleh Pejabat Pemerintahan untuk mengatasi persoalan konkret yang dihadapi dalam penyelenggaraan pemerintahan dalam hal peraturan perundang-undangan yang memberikan pilihan, tidak mengatur, tidak lengkap atau tidak jelas, dan/atau adanya stagnasi pemerintahan.

Dalam undang-undang tersebut dijelaskan pula prosedur penggunaan diskresi yang harus pejabat lakukan dan akibat hukum dari penggunaan diskresi jika terjadi kesewenang-wenangan. Berikut peneliti akan menjelaskan ketentuan diskresi berdasarkan Undang-undang Nomor 30 Tahun 2014.

Dalam pasal 22 ayat (2) tertulis bahwa setiap penggunaan Diskresi Pejabat Pemerintahan bertujuan untuk; (a) melancarkan penyelenggaraan pemerintahan, (b) mengisi kekosongan hukum, (c) memberikan kepastian hukum, (d) mengatasi stagnasi pemerintahan dalam keadaan tertentu guna kemanfaatan dan kepentingan umum.

Dalam pasal 24 menjelaskan Persyaratan Diskresi, Pejabat Pemerintah yang menggunakan Diskresi harus memenuhi syarat yaitu; (a) sesuai dengan tujuan Diskresi sebagaimana dimaksud dalam Pasal 22 ayat (2), (b) tidak bertentangan dengan ketentuan Peraturan Perundang-undangan, (c) sesuai dengan AUPB (Asasasas Umum Pemerintahan yang Baik), (d) berdasarkan alasan-alasan yang objektif, (e) tidak menimbulkan konflik kepentingan, (f) dilakukan dengan itikad baik.

Dalam pasal 25 ayat (1) menjelaskan bahwa penggunaan Diskresi yang berpotensi mengubah alokasi anggaran wajib memperoleh persetujuan dari atasan pejabat sesuai dengan ketentuan Peraturan Perundang-undangan.

Dalam Pasal 26 menjelaskan Prosedur Penggunaan Diskresi yaitu; (1) pejabat yang menggunakan Diskresi sebagaimana dimaksud dalam pasal 25 ayat (1) dan ayat (2) wajib menguraikan maksud, tujuan, substansi, serta dampak administrasi dan keuangan, (2) pejabat yang menggunakan Diskresi sebagaimana dimaksud pada ayat (1) wajib menyampaikan permohonan persetujuan secara tertulis kepada atasan pejabat, (3) dalam waktu 5 (lima) hari kerja setelah berkas permohonan diterima, atasan pejabat menetapkan persetujuan, petunjuk perbaikan, atau penolakan.

Dalam pasal 31 ayat (1) menjelaskan penggunaan Diskresi dikategorikan mencampuradukkan wewenang apabila; (a) menggunakan diskresi tidak sesuai dengan tujuan wewenang yang diberikan, (b) tidak sesuai dengan ketentuan pasal 26, 27, 28, dan/atau, (c) bertentangan dengan AUPB, ayat (2) akibat hukum dari penggunaan Diskresi sebagaimana dimaksud pada ayat (1) dapat dibatalkan.

Ahok sebagai pejabat pemerintah mempunyai hak untuk melakukan diskresi. Namun, keputusan Ahok dalam diskresi tersebut berpotensi melanggar peraturan 
yang ada. Oleh karena itu, sebaiknya Ahok terlebih dahulu mengkajinya apakah keputusannya ini tepat atau tidak, dan perlu adanya laporan langsung kepada Kementerian Dalam Negri sebelum bertindak.

Berdasarkan ketentuan yang tertera dalam undang-undang tersebut, KPK dapat menjadikannya sebagai rujukan untuk mengkaji dan mengambil tindakan apakah diskresi yang dilakukan oleh Basuki Tjahaja Purnama tersebut sudah sesuai dengan undang-undang yang berlaku, apalagi Gubernur DKI Jakarta tersebut juga menggunakan undang-undang tersebut sebagai landasan mengambil keputusan. Perlu diselidiki karena khawatir akan menimbulkan konflik kepentingan.

Berita terkait reklamasi dihasilkan dari liputan wartawan Tempo di lapangan, dengan melihat kondisi dan juga melakukan wawancara dengan narasumber. Sehingga berita tersebut lahir dari hasil konstruksi pemikiran wartawan yang telah melalui proses penggalian informasi perihal reklamasi Jakarta dari berbagai pihak. Paradigma berpikir wartawan Tempo dan pihak redaksi berpengaruh dalam menentukan arah atau makna yang ingin ditonjolkan pada berita tersebut sebelum diterbitkan.

Tempo mengkonstruksi diskresi yang dilakukan Ahok adalah sebuah keputusan yang tidak tepat. Redaksi kata-kata yang digunakan Tempo dalam membahas diskresi ditulis dengan gaya bahasa yang terkesan mengkritik, layaknya karakter Tempo. Terdapat pada salah satu judul berita yang Tempo tuliskan "Kontroversi Diskresi Ahok" pada isi berita Tempo mengatakan Ahok berlindung dibalik diskresi. Tidak hanya itu, Tempo juga secara tersirat ingin menyampaikan bahwa Sugianto Kusuma alias Aguan adalah aktor di balik kasus suap yang kini sedang diselidiki KPK tersebut. Walaupun Tempo memposisikan dirinya sebagai media yang netral, namun tidak dapat dipungkiri bahwa pada beberapa beritanya Tempo terlihat menyudutkan pihak-pihak seperti Ahok, Aguan, Teman Ahok, Sunny dan Cyrus.

Berita terkait reklamasi tersebut tersirat makna yang ingin disampaikan oleh pihak Tempo kepada pembaca bahwa ada hal urgent dalam proyek reklamasi yang harus diperhatikan. Polemik reklamasi tidak hanya sebatas masyarakat nelayan yang terkena dampak buruknya, tetapi ada masalah lain yang juga berdampak besar, yaitu menyangkut ekonomi sosial politik.

Pencemaran lingkungan, dampak dari reklamasi memang tidak jauh dari pencemaran lingkungan jika pemerintah dan pengembang tidak memperhatikan dan mengkaji dengan baik, saat ini dampak buruk terhadap lingkungan sudah terlihat dan kajian amdal belum dilakukan dengan baik oleh pemerintah daerah dan pengembang. Peneliti mencari data dan melakukan konfrimasi perihal dampak lingkungan, bahwa proyek tersebut sudah mengalami 'cacat bawaan' karena prosesnya melanggar beberapa ketentuan hukum seperti UU No. 27 tahun 2007 dan revisinya No. 1 Tahun 2004 Pengelolaan Wilayah Pesisir dan Laut, maupun UU No. 32 Tahun 2009 tentang Perlindungan dan Pengelolaan Lingkungan Hidup yang didalamnya tercantum soal perlunya dokumen analisis dampak lingkungan. Data tersebut peneliti dapatkan dari 
Lembaga Bantuan Hukum Jakarta dan juga Wahana Lingkungan Hidup Jakarta, lembaga tersebut merupakan salah dua dari koalisi yang melakukan advokasi untuk reklamasi Jakarta.

Jika dikaji dari segi ekonomi politik bahwa kegiatan reklamasi melahirkan kecacatan regulasi sejak awal. Pembuatan regulasi melahirkan kongkalikong yang melibatkan pengusaha dan pelaku politik guna untuk memuluskan aturan main agar proyek tersebut dapat berlangsung. Ketidakadilan ekonomi lahir dari sini, keputusan reklamasi bukan lagi menjadi solusi untuk kepentingan bersama tetapi menjadi kepentingan bagi para pemilik modal domestik maupun asing yang bekerja sama dengan pemangku kewenangan regulasi. Akibatnya masyarakat pesisir, nelayan tradisional, pemilik usaha skala kecil yang bergantung pada ruang laut, termarjinalkan dan tertindas secara langsung. .

Kecacatan hukum yang paling dominan adalah aturan kontribusi tambahan yang hingga kini tak berujung pengesahannya sampai terjadi penangkapan oleh KPK. Tempo juga ingin menyampaikan bahwa kasus suap tidak hanya berhenti pada Ariesman Widjaja dan Sanusi. Tempo mengidentifikasi bahwa ada pihak lain yang juga ikut andil dalam penyelewengan tersebut, seperti Sugianto Kusuma alias Aguan, Sunny Tanuwidjaja, dan juga Teman Ahok serta Cyrus. Dari berita Tempo dapat dinilai bahwa Ahok melakukan penyelewengan jabatan dan tidak serius dalam menangani kasus reklamasi tersebut, malah menjadikannya sebagai ladang keuntungan oleh pihak-pihak tertentu.

Jakarta darurat reklamasi dengan segala polemik yang terjadi di dalamnya, media sebagai ruang informasi publik sudah seharusnya memberikan informasi perihal suatu peristiwa yang terjadi sehingga permasalahan tersebut mendapat pengawalan dan pengawasan secara bersama oleh masyarakat.

\section{Simpulan}

Define problems. Dalam pemberitaan reklamasi Jakarta, Tempo mengkritisi diskresi yang dilakukan Ahok untuk reklamasi Jakarta. Diskresi yang dilakukan oleh Basuki Tjahaja Purnama dianggap sebagai sebuah terobosan baru yang memiliki catatan penting di dalamnya. Diskresi yang dianggap sebagai jalan tengah ternyata menjadi sumber dari masalah suap yang kini sedang diselidiki KPK. Dengan karakter Tempo yang berani dan kritis, Tempo coba membongkar kebusukan yang terjadi dalam kasus reklamasi. Masalah regulasi yang tidak memiliki ketegasan sampai pada dampak buruk yang diakibatkan dari reklamasi. Tidak hanya itu Tempo terlihat menyudutkan Teman Ahok, Sunny Tanuwidjaja dan Cyrus dalam pembahasan terkait aliran dana suap tersebut. Namun kebenaran informasi yang Tempo paparkan dalam beritanya menjadi kurang relevan, karena narasumber yang anonim dan tidak cukup cover both side.

Diagnose causes. Tempo menitik beratkan bahwa Ahok adalah orang yang bertanggungjawab atas polemik diskresi yang terjadi. Keputusan tersebut berdampak pada penyelewengan yang dilakukan oleh oknum pejabat daerah dan beberapa pihak 
terkait seperti pengembang dan juga Teman Ahok dalam kasus reklamasi Jakarta tersebut. Tidak hanya itu, keputusan yang dikeluarkan oleh Ahok pada Maret 2014 tersebut dipertanyakan dasar hukum yang melandasi keputusan tersebut. Mengapa demikian? Karena dasar undang-undang yang kini menjadi payung hukum yang digenggam Ahok, belum disahkan ketika diskresi tersebut dicetuskan. UndangUndang Nomor 30 Tahun 2014 tentang Administrasi Pemerintahan tersebut di keluarkan pada akhir tahun 2014. Tempo juga mengarahkan pembaca bahwa Sugianto Kusuma alias Aguan ikut menghadang kontribusi tambahan 15 persen yang ditetapkan Basuki Tjahaja Purnama.

Make moral judgement. Pembenaran mengenai penyelewengan yang terjadi dalam tubuh reklamasi, Tempo jabarkan melalui data-data yang diperolehnya dari hasil investigasi. Tempo juga menyampaikan bahwa ada masalah yang urgent dalam kasus reklamasi Jakarta. Masalah tersebut tidak hanya perihal korupsi dan lingkungan, tapi juga menyangkut regulasi, ekonomi dan juga hajat hidup orang banyak. Reklamasi memiliki dampak buruk jangka panjang jika tidak diperhatikan dan dikaji dengan benar. Secara tidak langsung Tempo melakukan sosial learning kepada pembacanya, yang dimaksud adalah Tempo memberikan pencerahanpencerahan kepada pembacanya untuk membuka mata dan telinga agar bersama melakukan pengawasan dalam melihat kasus reklamasi Jakarta tersebut. Namun, Tempo tidak menyatakan sikap apakah reklamasi Jakarta tetap dilanjutkan atau dihentikan dalam artian menolak reklamasi.

Treatment recommendation. Tempo secara tidak langsung menyerukan kepada Komisi Pemberantasan Korupsi untuk melakukan penyelidikan dengan benar dan mendalam, membongkar kasus suap reklamasi dan ketepatan diskresi yang dilakukan oleh Ahok. Menindak penyelewengan yang telah dilakukan oknum-oknum pencari keuntungan dalam kasus reklamasi Jakarta tersebut.

Tempo sebagai salah satu pelaku komunikasi massa sudah menjalankan fungsinya sebagai media yang menyampaikan informasi kepada khalayak dan sebagai pengawasan pada suatu peristiwa dengan melakukan peringatan dan kontrol sosial. Dalam pemberitaan reklamasi, Tempo secara tidak langsung menggiring pembacanya untuk memperhatikan kasus reklamasi Jakarta. Sesuai dengan kajian komunikasi massa yang merupakan sejenis kekuatan sosial yang dapat menggerakkan proses sosial ke arah suatu tujuan yang telah ditetapkan terlebih dahulu.

Tempo merupakan media massa yang tergolong media yang memiliki kredibilitas cukup tinggi. Dalam memperoleh informasi Tempo pun tak jarang melakukan investigasi mendalam. Namun, sebaiknya Tempo mencantumkan narasumber yang ditemuinya untuk memperoleh informasi, walaupun dalam dunia jurnalistik merahasiakan identitas narasumber atau narasumber yang anonim adalah hal yang diperbolehkan, namun itu dapat berpengaruh pada sudut pandang pembaca apakah narasumber tersebut dapat dipercaya informasinya atau tidak. Sehingga nilai berita yang disuguhkan menjadi tidak kuat kebenarannya. Sebaiknya Tempo meminimalisir narasumber yang anonim. 
Fuji Lara Sakti Afdiningsih, H. A. Sihabudin, Puspita Asri Praceka: Framing Pemberitaan ... 69

\section{Daftar Pustaka}

Eriyanto. 2007. Analisis Framing. Yogyakarta: LKiS

Sobur, Alex. 2006. Analisis Teks Media Suatu Pengantar. Bandung: Remaja Rosdakarya

Cnnindonesia. 2016. KPK Selidiki Diskresi Reklamasi Ahok Takut. http://www.cnnindonesia.com/nasional/20161006194135-12-163826/kpkselidiki-diskresi-reklamasi-ahok-tak-takut/. 08 Juni 2016, Pukul 15:53 WIB

Infohukum KKP. 2016. Draft Undang-undang. http://infohukum.kkp.go.id/index.php/hukum/download/552/?type_id=1. 23 Oktober 2016, Pukul 21:15 WIB

Tempo.co. 2016. Diskresi Ahok Ini yang Dipersoalkan KPK. https://m.tempo.co/read/news/2016/05/24/063773627/diskresi-ahok-ini-yangdipersoalkan-kpk. diakses 08 Juni 2016, Pukul 16:25 WIB

Republika.co.id. 2016. Ahok Salah Artikan Diskresi.

http://nasional.republika.co.id/berita/nasional/pemprovjabar/ 16/05/26/o7rx01377icw-ahok-salah-artikan-diskresi. 08 Juni 2016, Pukul 15:53 WIB 